\title{
Transformation of Grain Production and the Rice Frontier in Modernizing China
}

\author{
MOTOKI Yasushi \\ Faculty of Liberal Arts, Saitama University, Saitama 338-8570, Japan
}

\begin{abstract}
This paper examines the transformation of the Chinese grain production during the process of modernization after the economic reform/open door policy, especially focusing on the unshakable position that rice production has historically occupied in China. The first section illustrates how food crops decreased in Chinese agriculture in the period of 1985-2001. Furthermore, the rice production in the south stagnated or decreased, while it gradually became more important in northern China. The second section shows the pattern of local rice production in the Northeast, within northern China, and how a new rice frontier emerged in the north of Heilongjiang Province and the west of Jilin Province (both of which are cold and dry areas with alkaline soil). The third section is devoted to a case study of the rice frontier in the Northeast, which deals with the role of rice production and how production was either supported or restricted. We come to the hypothesis, as a conclusion, that development of the rice production in the Northeast did not only mean an actual increase in Japonica type of rice (high quality rice), but it also had an impact on the situation in the southern rice-growing areas. This might amount to a challenge to the South imposed by the North in the near future
\end{abstract}

Key words: economic reform, Northeast China, rice frontier, policy judgment, food problems

\section{Introduction}

When the Chinese open door policy started in 1978, a quarter-century after World War II when reforms of the socialist economic system were initiated, this had enormous historical repercussions on traditional society. Rapid economic development was generated by privatization, industrialization, the trend from rural to urban areas-urbanization-as well as commercialization.

Brown (1995) attracts our attention to the fact that we may face serious food and environmental problems if a densely populated society becomes more industrialized, and warns us that 'if China emerges as a food-importing nation, this may be unsustainable for the global population and environment.' Fortunately, this is not the case yet. However, the fact that the Chinese government upgraded the Land Control Office to the Ministry of Country Resources, illustrates that supply and demand of food, water supply and environmental problems are important subjects on the political agenda. Of course, food and environmental problems are not problems of China alone, but big issues of the entire world. We can therefore say that research of trends in China is part of a worldwide study in this respect.

One of the objectives of this study is to show how, in a modernizing China, social changes arise from the way land is used and what the implications for the future are. The term 'land use' refers to the relationship between human beings and nature, and how an ecological system affects a developing social system. Research on land use is extremely meaningful for modern China as various problems such as the demand and supply of food, distribution of resources, regional income disparity or environmental problems all closely relate to land use system. A sufficient understanding in land use enables us to solve some of the problems mentioned above. The study deserving particular attention is the LUCC (Land Use/Cover Change) Programme. ${ }^{1}$

There is already abundant research on the change in land use/cover after the economic reforms in China: Huang, Rozelle, and Resegrant (1999) state that China's socioeconomic forces have been exerting a very different influence on 
rice, wheat and maize since 1980. And Ying (1999) shows how the regional disparities between the coast and the interior have become more significant than the traditional NorthSouth inequality in the Chinese economy. Zhang (2000) considered the background of great changes in the food production in China and its distribution in the past 50 years. He said that such changes in food production brought about comparatively low benefits, while differences in the market and transportation were other contributory factors. Motoki and Bilaledin (2003) examined when and how economic reforms and the market economy influenced the peripheral regions, Ghulja County of Xinjiang Uighur Autonomous Region is used as a concrete case study; this region shows not only a reorganization of the farming system but also dangerous effects on the natural balance of the environment. Lindert (1999) shows that China's average quality of agricultural topsoil has probably not declined and the spread of cities and other non-agricultural land uses have indeed taken land away from agriculture since the 1930s. This is what emerges from studies on natural conditions. Rozelle, Veeck, and Huang (1997), for example, hypothesized that environmental degradation has had a major effect on grain production in many of China's agricultural areas. Cai (1998) pointed out that the most urgent problem in land-degraded regions is securing resources for basic living. Otsubo (2002) questioned sustainable land use in China: "Although crop production can be increased by improving temperature, water, and soil conditions and agricultural technology, we must keep in mind that many environmental problems might result from these activities" in the future. Meanwhile, conventional agriculture is facing serious resource and environmental problems in China as Wen and Pimentel (1992) have pointed out. The case study by Muldavin (1997) shows that all green-manure cropping ended one year after the implementation of reforms in Zhaozhou County (Heilomgjiang Province) as these crops were replaced with cash crops, resulting in a 50 percent decline in green-manure area.

On this topic, Zhang and Makehan (1992) point out that the information obtained in this study is limited. The details of the current situation are not based on chronological data. Bito (2000) also elaborates on the fact that a number of research models are not sufficiently grounded in actual conditions and that therefore further research with empirical knowledge on sub-models is required.

The writer would like to point out two fundamental problems in previous research:

First the view-point that production of cereals for food as direct consumption will decrease, while cereals for feed and thus producing meat will increase (examples: Nakaya and Shimizu 2002). Although it is meaningful in some cases to divide food crops into two groups, this does not sufficiently reflect rice growing habits in Asia. As mentioned by Bito as well, we have useful experience on this topic in Japan and South Korea during the process of economic development (example, Motoki 1997). Although the example of Japan does not always apply, a comparison with Japan is not meaningless.

The second point is the general assumption that a change in the consumption structure caused by industrialization and urbanization will lead to agricultural changes in rural areas. ${ }^{2}$ However, in the case of China-excluding western China-we should bear in mind regional environmental differences between the north and the south to explain the issue of land use.

The above two points have not been considered sufficiently in previous studies. ${ }^{3}$ This study will pay particular attention to the above two points and examine the transformation of Chinese cereal production during the process of modernization. In concrete terms, this means focusing on the unshakable position that rice production has historically assumed in China. The following points will be raised:

1) Changes in contrasting traditional characteristics (agricultural land use) between the North and the South based on regional differences in the natural environment.

2) Changes in the regional pattern of rice growing after the 1980 reforms in Northeast China.

3) Factors that enhanced or restricted rice growing development.

4) Changes in the role of rice growing in the Northeast and in the whole country. 
As for the research method, statistical material will be used for points 1 and 2; while point 3 will be based on a field study and point 4 raise the future significance of rice production under changing land use conditions.

\section{North versus South: Changes in the Structure of Grain Production after Economic Reforms}

\section{Declining importance of food crops}

According to the China Statistical Yearbook, agricultural crops are classified into three categories: grain crops (cereals such as rice, wheat, corn, soybeans and tubers); cash crops (oilbearing crops such as peanuts and rapeseed, cotton, fiber crops, sugar crops like sugarcane and beetroot, tobacco, mulberry, tea, fruits); and other crops, including vegetables.

In general we can observe, with changes in land use and economic development, a tendency away from traditional crops like cereals towards commercial crops. China is no exception in this sense. Thus we notice that, since the beginning of reforms in 1978, China's total agricultural area of crops increased by 51.21 million ha (3.4\%), from $1,557.08$ million ha to $1,501.05$ million ha. However, as far as cereals are concerned, we can observe a decrease of 145.07 million ha $(12 \%)$, from $1,205.87$ million ha to $1,060.80$ million ha. In relation to the total agricultural crops, food crops decreased from $80.3 \%$ to $68.1 \%$ (Table 1 ).

Figure 1 divides food crops into rice, wheat, corn, soybeans, tubers and others, and shows changes in the sowing area in relation to the production volumes. As for the sowing area, cereals like rice, wheat and corn etc. that in 1978 took up the largest surface, decreased rapidly. Other cereals like soybeans and tubers also greatly decreased. We can notice an increase in corn production, whereas the total sowing area of rice and wheat show decreasing tendencies. Between 1978 and 2001, rice decreased by $16 \%$ (from 344.21 million ha to 288.12 million ha), wheat shrank by $15 \%$ (from 191.83 million ha to 246.64 million ha), but corn grew by $22 \%$.

The production volume greatly increased in the 1990s when compared with the overall productive surface, while it slightly decreased after 2000. This means that the productivity of land for food crops has been greatly improved throughout China during the process of economic reforms. How then can we explain a recent decrease in food production, especially as far as rice, wheat and corn are concerned? In China food used to be one of the agricultural

Table 1. Changes in the sown areas of grain crops and other farm crops in China

(unit: 1,000 ha)

\begin{tabular}{|c|c|c|c|c|c|c|c|c|c|c|}
\hline \multirow{3}{*}{$\begin{array}{l}\text { Year } \\
1978\end{array}$} & \multirow{3}{*}{$\begin{array}{c}\text { Total sown area } \\
\text { of farm crops }\end{array}$} & \multirow{2}{*}{\multicolumn{2}{|c|}{$\begin{array}{c}\text { Sown area of grain crops \& } \\
\% \text { to total farm crops }\end{array}$}} & \multicolumn{5}{|c|}{ Composition $(\%)$ of main grain crops } & \multirow{2}{*}{\multicolumn{2}{|c|}{$\begin{array}{l}\text { Vegetables } \\
\text { orchards }\end{array}$}} \\
\hline & & & & \multirow{2}{*}{$\frac{\text { Rice }}{28.5}$} & \multirow{2}{*}{$\frac{\text { Wheat }}{24.2}$} & \multirow{2}{*}{$\begin{array}{r}\text { Corn } \\
16.6\end{array}$} & \multirow{2}{*}{$\frac{\text { Beans }}{-}$} & \multirow{2}{*}{$\frac{\text { Tubers }}{9.8}$} & & \\
\hline & & 120,587 & 80.3 & & & & & & 3,331 & 1,657 \\
\hline 1980 & 146,381 & 117,234 & 80.1 & 28.9 & 24.6 & 17.1 & - & 8.7 & 3,163 & 1,783 \\
\hline 1985 & 143,626 & 108,845 & 75.8 & 29.5 & 26.8 & 169.3 & - & 7.9 & 4,753 & 2,736 \\
\hline 1990 & 148,363 & 113,466 & 76.5 & 29.1 & 27.1 & 18.9 & - & 8.0 & 6,338 & 5,179 \\
\hline 1991 & 149,586 & 112,314 & 75.1 & 29.0 & 27.6 & 19.2 & 8.2 & 8.1 & 6,546 & 5,318 \\
\hline 1992 & 149,008 & 110,560 & 74.2 & 29.0 & 27.6 & 19.0 & 8.1 & 8.2 & 7,031 & 5,818 \\
\hline 1993 & 147,741 & 110,509 & 74.8 & 27.5 & 27.4 & 18.7 & 11.2 & 8.3 & 8,084 & 6,432 \\
\hline 1994 & 148,241 & 108,544 & 73.2 & 27.8 & 26.7 & 19.5 & 11.7 & 8.5 & 8,921 & 7,264 \\
\hline 1995 & 149,879 & 110,060 & 73.4 & 27.9 & 26.2 & 20.7 & 10.2 & 8.6 & 9,515 & 8,098 \\
\hline 1996 & 152,381 & 112,548 & 73.9 & 27.9 & 26.3 & 21.8 & 9.4 & 8.7 & 10,491 & 8,553 \\
\hline 1997 & 153,969 & 112,912 & 73.3 & 28.1 & 26.6 & 21.1 & 9.9 & 8.7 & 11,288 & 8,648 \\
\hline 1998 & 155,706 & 113,787 & 73.1 & 27.4 & 26.2 & 22.2 & 10.3 & 8.8 & 12,293 & 8,535 \\
\hline 1999 & 156,373 & 113,161 & 72.4 & 27.6 & 25.5 & 22.9 & 9.9 & 9.2 & 13,347 & 8,667 \\
\hline 2000 & 156,300 & 108,463 & 69.4 & 27.6 & 24.6 & 21.3 & 11.7 & 9.7 & 15,237 & 8,932 \\
\hline 2001 & 155,708 & 106,080 & 68.1 & 27.2 & 23.3 & 22.9 & 12.5 & 9.6 & 16,402 & 9,043 \\
\hline
\end{tabular}

Source: China Statistical Yearbook, 2002. 

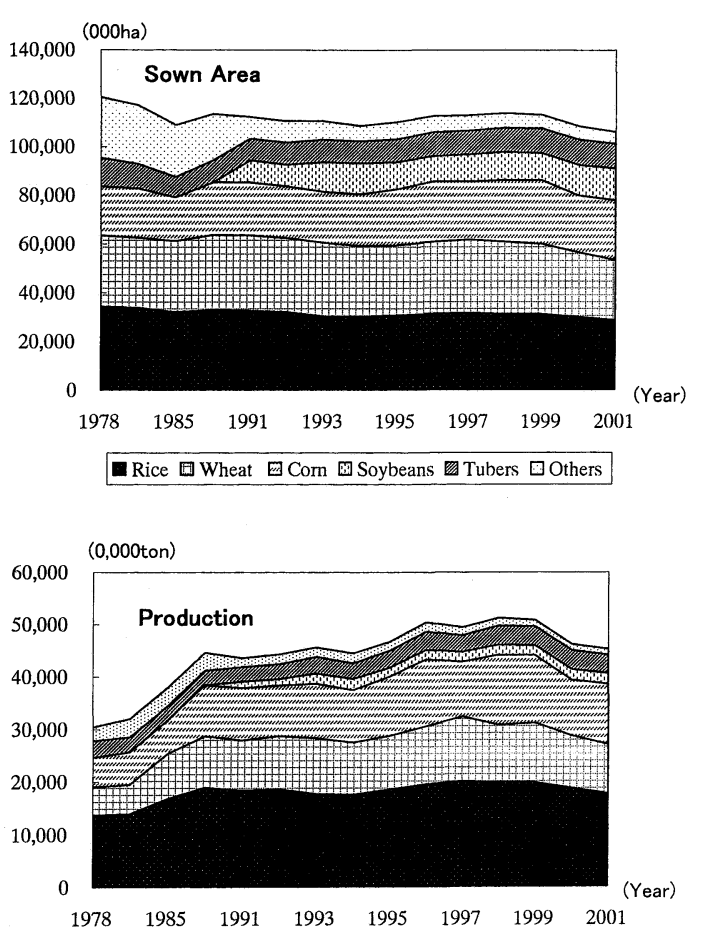

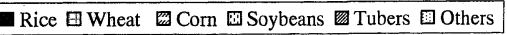

Figure 1. Changing composition of food crops by sown area and amount of production in China.

products whose distribution and price were within government control; by means of contract purchasing, the government-owned enterprise acquired food. The purchasing price was raised twice between 1994 and 1996 which led to big increases in production. After 1997, however, prices fell and contract purchasing was reduced after 1999 so that 1999 was the first year with a readjusted structure. The number of items with protected prices as well as the production area were greatly reduced (Ikegami 2002).

The food production environment generally improved in the process of the economic reforms so that food crop production not only increased but was also corrected to eliminate surplus production. The share of rice, wheat and corn in the food crops changed from $28.5 \%$, $24.2 \%$, and $16.6 \%$ in 1978 to $27.2 \%, 23.3 \%$, and $22.9 \%$ in 2001 ; altogether these three crops increased from $69.3 \%$ to $73.4 \%$. The increase in corn can be explained by the demand of corn for feeding livestock as consumption patterns changed in recent years. Higher demand for corn goes hand in hand with expanded production of cash crops like vegetables and fruits. The area used to produce vegetables and fruits increased about fivefold between 1978 and 2001-160 million ha for vegetables and $90 \mathrm{mil}$ lion ha for fruit trees.

\section{Food crop production and the north/south dis- tribution}

China has traditionally been divided into northern and southern parts with the Qinling Mountain Range and the Huai River as the border: the north consists of the area north of the Yellow River, while the south stretches southward from the Changjiang River. It may be noteworthy that the south-compared with the northern part-has been exposed to foreign influences for much longer (Bishop 1922). Today's open door policy equally started off in the south with the establishment of special economic zones and areas open to foreign investment. When examining how the economic reforms changed traditional land use, we must take into account this division of the country into the northern and southern part.

Two different types of field have traditionally been found in China: ordinary fields for wheat cultivation in the north of the Yellow River and paddy-fields in the south. In his report Land utilization in China Buck (1941) clearly differentiates between the following eight areas: spring wheat, winter wheat/millet, winter wheat/kaoliang (coarse grain) in the north; rice/wheat, rice/tea, Sichuan rice, rice with double crops and southwestern rice in the southern part of the country. The difference of a dry, cold north and a warm, humid south is reflected in the utilization of land. In addition, loess soil in the north is another factor influencing land use.

Millet and kaoliang, as listed in Buck's classification, are strongly resistant to drought and have therefore traditionally been grown on land with scant water supply and the danger of dryness. ${ }^{4} \mathrm{Hu}$ (1962) pointed out that while corn, rice or tubers were gradually being cultivated on a more intensive scale, crop conversion was not all that easy for millet and kaoli- 
Table 2. Composition (\%) of the grain crops in northern and southern China

\begin{tabular}{|c|c|c|c|c|c|}
\hline & \multirow{2}{*}{ Year } & \multicolumn{2}{|c|}{ Northern } & \multicolumn{2}{|c|}{ Southern } \\
\hline & & Area & Production & Area & Production \\
\hline \multirow[b]{2}{*}{ Rice } & 1985 & 7.0 & 7.1 & 93.0 & 92.9 \\
\hline & 2001 & 13.4 & 13.4 & 86.6 & 86.6 \\
\hline \multirow[b]{2}{*}{ Wheat } & 1985 & 69.3 & 68.4 & 30.7 & 31.6 \\
\hline & 2001 & 68.2 & 73.2 & 31.8 & 26.8 \\
\hline \multirow[b]{2}{*}{ Corn } & 1985 & 72.7 & 76.1 & 27.3 & 23.9 \\
\hline & 2001 & 74.9 & 77.6 & 25.1 & 22.4 \\
\hline
\end{tabular}

Source: China Statistical Yearbook, 1986 and 2002.

ang as they were being used as feed and fuel and thus assumed very diverse functions. In fact, rice was mainly consumed in the middle and south of China right before the reforms, whereas the area north of the Yellow River and the Huai River was used for other crops such as wheat, cereals (millet), kaoliang, etc. which constitute daily foods (Sum 1978). However, the latter drastically decreased after the 1990s (see Figure 1).

Table 2 illustrates how the ratio between the three major crops (rice, wheat and corn) changed between 1985 and 2001 in a north/ south comparison. It is clear that wheat and corn prevail in the north, while rice is favoured in the south - a tendency that has not been changed despite the reform process but even grown stronger especially in the case of corn in the north.

As far as rice is concerned, its proportion increased in the north from $7 \%$ in 1985 to $13 \%$ in 2001 , while it decreased in the south from $93 \%$ to $86 \%$. Although rice is still clearly prevalent in the south, it is the crop that shows the greatest change among the three cereals.

In the same context, we should pay attention to the varieties of rice planted: Indica type in the south, Japonica type in the north. This may have further implications for the future of Chinese rice cultivation.

\section{Geographical examination}

The tendencies described previously can be found fairly generally on the level of provinces and autonomous regions (Figure $2 ; \mathrm{a}, \mathrm{b}$, and c). As for rice, the decrease in the main ricegrowing areas such as Jiangxi, Sichuan, Guang- dong, Jiangsu, Zhejiang, Hubei, and Fujian provinces is noteworthy. However, at present there are a few places with unexpectedly small decreases in production volume. The reason for this is thought to be the introduction of a rice variety (Hybrid variety), ${ }^{5}$ which provides higher yields even without double cropping (Huan and Luo 1996). In the year 2000, hybrid varieties reached a proportion of $50 \%$, Indica even $70 \%$. Despite all this, production clearly declined in Hubei, Guangdong, Fujian, and Zhejiang provinces. A typical province like Heilongjiang, which showed higher production volumes, also increased the area of cultivation; further details on this later.

Although in the case of wheat a general decreasing tendency is noticeable, this does not apply to entire provinces or autonomous regions. Henan and Hubei provinces are examples of increased cultivation area and increased production volumes. Except for Shandong Province, where cultivation area decreased without a decrease in production volume, most places show decreasing cultivation area and production volumes. Heilongjiang Province is a typical example of this.

As far as corn is concerned, its cultivation area and production amount increased in most provinces and autonomous regions - a trend particularly remarkable in the north-Jilin, Inner Mongolia, Heilongjiang, Henan, Hubei, Shandong, and Liaoning among other regions. The use of hybrid corn, by the way, reached $90 \%$ in these regions.

I wish to pay particular attention to growing food production in the three northeastern provinces of Heilongjiang, Jilin, and Liaoning, al- 

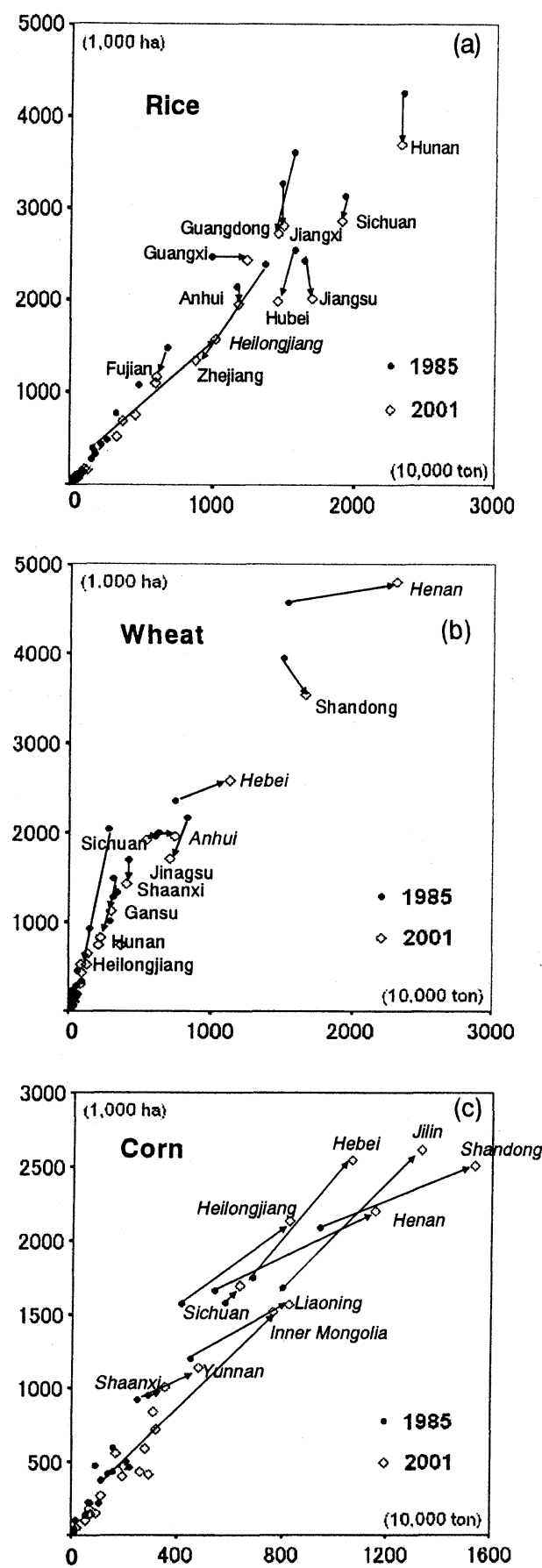

Figure 2. Changes in the sown area and yield of main crops by province/autonomous region.

though food crop cultivation in China as a whole shows decreasing tendencies.

\section{The Development Pattern of Food Production in the Northeast}

\section{Rising importance of the Northeast as a food production area}

Table 3 shows the agricultural status during 1985-2001 in the Northeast district (hereafter abbreviated to 'the Northeast'), compared to the whole country, by index both of the total sown area of farm crops and the sown area of grain crops.

According to this, the Northeast total sown area of farm crops is about 11-12\% of the whole of China, and the ratio decreased within 16 years. However, when restricting ourselves only to food crops, we note that the Northeast occupies a $12-15 \%$ share of the whole country, even with a slightly increasing tendency. As for the percentage of food (grain) crop to total farm crops by sown area, the Northeast increased to $84.4 \%$ (2001) from $81.9 \%$ (1985), while in the case of the whole country, this percentage decreased from $75.8 \%$ (1985) to $68.1 \%$ (2001). We can thus recognize that there is a marked inclination to food crop production in the Northeast in recent years.

Traditionally in the Northeast, crops such as kaoliang, millet, corn, and wheat, except soybean (which have been exported to the world markets), have been mainly cultivated for reasons of self-sufficiency in the past (1930s) (Minami-Mansyu-Tetudo Kabushikikaisha Sangyobu 1932). This situation continued to exist until the beginning of the 1980s. However, food crop production figures in recent years have not shown their strong traditional levels. Kaoliang and millet mostly decreased in the whole country as seen in the first chapter (see Figure 1 , sown area).

In 2001 in the Northeast, the shares of the various crops in relation to sown areas were as follows: $17.4 \%$ rice, $3.6 \%$ wheat, $39.7 \%$ corn, $29.7 \%$ beans; production volumes: $28.7 \%$ rice, $2.0 \%$ wheat, $49.4 \%$ corn, $12.1 \%$ beans. Therefore, we notice a new trend: the growth in the Northeast was mainly due to increased corn and rice production, while wheat continued to decrease. 
Table 3. Importance of the Northeast in Chinese agriculture

(unit: 1,000 ha)

\begin{tabular}{|c|c|c|c|c|c|c|c|c|c|}
\hline & \multicolumn{2}{|c|}{ Northeast } & \multicolumn{2}{|c|}{ National } & \multicolumn{2}{|c|}{ Weight of Northeast } & \multicolumn{3}{|c|}{ Weight of grain crops } \\
\hline Year & $\begin{array}{l}\text { Total sown } \\
\text { area of farm } \\
\text { crops (A) }\end{array}$ & $\begin{array}{l}\text { Total sown } \\
\text { area of grain } \\
\text { crops (B) }\end{array}$ & $\begin{array}{l}\text { Total sown } \\
\text { area of farm } \\
\text { crops (C) }\end{array}$ & $\begin{array}{l}\text { Total sown } \\
\text { area of grain } \\
\text { crops (D) }\end{array}$ & $\begin{array}{l}\text { A/C } \\
(\%)\end{array}$ & $\begin{array}{l}\text { B/D } \\
(\%)\end{array}$ & $\begin{array}{c}\text { Northeast } \\
\text { B/A } \\
(\%) \\
\end{array}$ & $\begin{array}{c}\text { National } \\
\text { D/C } \\
(\%)\end{array}$ & Difference \\
\hline 1985 & 352 & 15 & . & 1 & 11 & 12.3 & 81.9 & 75.8 & 6.1 \\
\hline 1991 & 16,319 & 14,059 & 149,586 & 112,314 & 10.9 & 12.5 & 86.2 & 75.1 & 11.1 \\
\hline 2001 & 18,844 & 15,899 & 155,708 & 106,080 & 12.1 & 15.0 & 84.4 & 68.1 & 16.3 \\
\hline
\end{tabular}

Source: China Statistical Yearbook, 1986, 1992, 2002.

Furthermore, what should be noticed here is the fact that the relative importance of corn and rice as well as traditional beans has risen not only in the Northeast but in whole country.

Since 2001, the Northeast corn production occupies $26 \%$ of the whole country in both of sown area and production quantity. As for the national ranking of corn production (sown area) in the northeastern provinces, Jilin $(2,609.5$ thousands ha) ranked first with Heilongjiang $(2,132.7)$ and Liaoning $(1,566.8) 5$ th and 6th, respectively.

As for rice, the relative importance of the Northeast is increasing to $9.6 \%(2,769.4$ thousands ha) of the national total in sown area and to $9.6 \%(1,722.7$ million ton) in production amount. Over a period of 17 years the relative importance of each of these three provinces has also increased. Especially Heilongjiang, which is located in the northernmost part, is remarkable as its national ranking went up to 9th place (in both side of sown area with 1,567 thousands ha and production quantity with $1,016.3$ million ton) in 2001 .

\section{Development pattern of food production within the Northeast}

Figure 3 shows the trends in grain cultivation area and production amounts, based on an index set in 1985. Although, according to this figure, the cultivation area for the three provinces of the Northeast was virtually stagnant, the amount of production increased rapidly. Furthermore, we can also notice drastic changes from south to north as far as corn and rice are concerned. In this case, although the growth of wheat in Liaoning Province is conspicuous, it has not really increased in absolute terms.

Therefore-with this minor exception-we can state that the inclination of food crops has progressed from the south to the north in this area. This means that the trend towards increased production of corn and rice started in 1985 in Liaoning Province, spread to Jilin in 1991 and finally, with a certain time-lag, to Heilongjiang in 2001. If the rate of the sown area of food crops to the total sown area of the agricultural products as of 2001 is seen, this is 79.8\% for Liaoning Province, $85.9 \%$ for Jilin, and $85.4 \%$ for Heilongjiang. Although this is not a really noticeable regional difference, it shows that a shift similar to the national trend is taking place within the Northeast.

Looking at the geographical side of the above change, a marked trend of changing local composition can be noticed among the three provinces of the Northeast in the case of corn and rice (Figure 4). As for corn, we do not see a large difference in the relative importance among the three provinces. However, in the case of rice, Heilongjiang takes up the front place, while Liaoning and Jilin fall behind. As of 2001, crop production in Heilongjiang occupied over $56.6 \%$ of the sown area and represented over $59 \%$ of the total quantity of production. This means that the frontier of rice growing in Northeast moved northwards. But to be precise we should also mention new areas in the western part (inland area) as well through the central part from the eastern part of Northeast, as the author (Motoki 2000) pointed out with the example of Jilin Province. 
Heilongjiang (Total Grain)

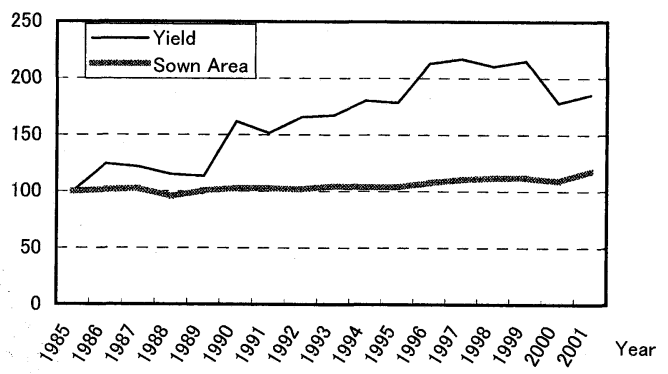

Jilin (Total Grain)

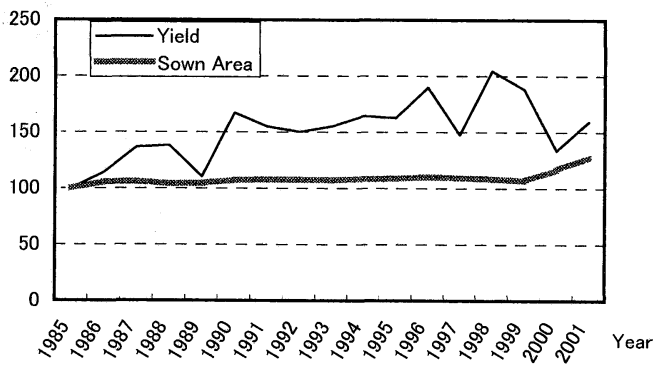

Liaoning (Total Grain)

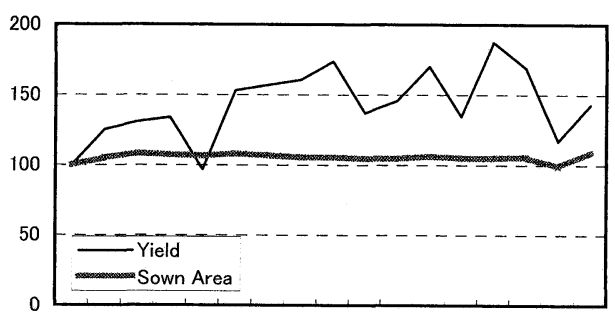

की
Heilongjiang (Yield by Main Crop)

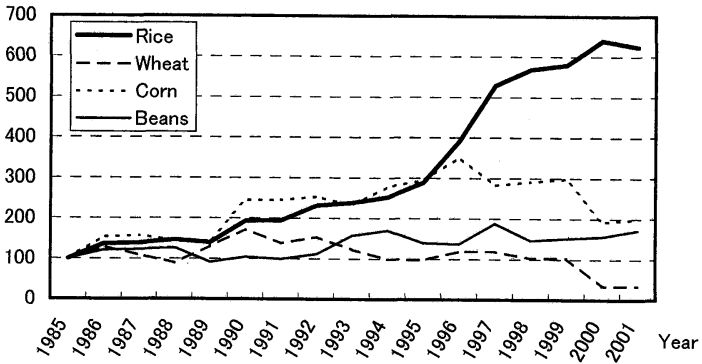

Jilin (Yield by Main Crop)

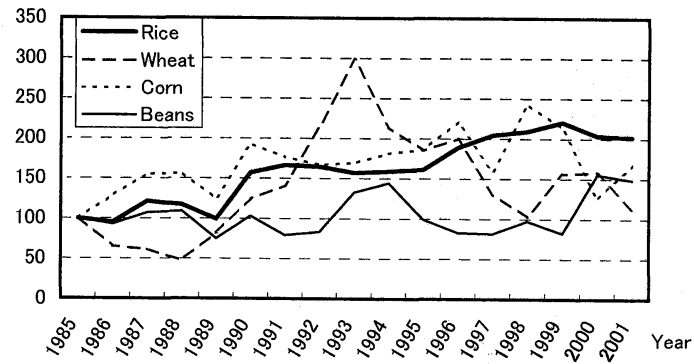

Liaoning (Yield by Main Crop)

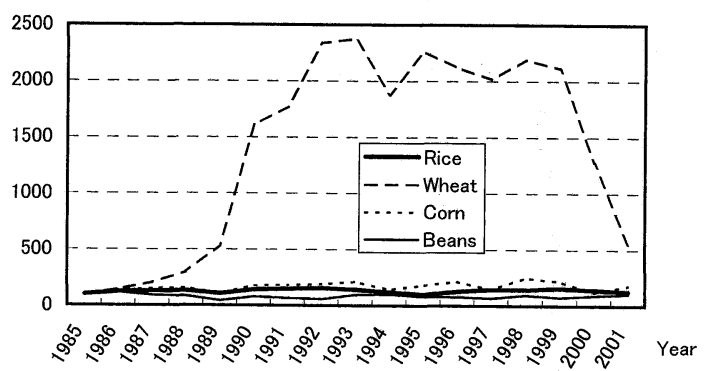

Figure 3. Trends of production in the Northeast.

\section{The rice development history to the northeast and the characteristics of frontier}

If rice crops were historically located in the southeastern part of Liaoning Province or Jilin, ${ }^{7}$ this can be explained by the climatic environment. The annual precipitation in the three provinces in question is as follows: Liaoning Province 400-1,200 mm, Jilin 350-700, Heilongjiang 250-700 mm (Wang and Zhou 2000: Table 1-1). The southern part of the northeast is therefore a natural environment for rice crops. Under such an environment, rice growing was developed by Koreans who were skillful in cultivation, and was after that encouraged under the Japanese colonial policy (Lee 1932). The Korean colonization in the State of Manchuria' led to irrigation and drainage.

As for the topographical feature of the rice fields, these were mostly on low-lying wetland. In the 1980s however-according to $\mathrm{Li}$ and Shi (1988: Figure 13)-food production areas for mainly rice were limited to the southeastern part of Liaoning Province. Even multiple food production areas consisted of a little rice with 

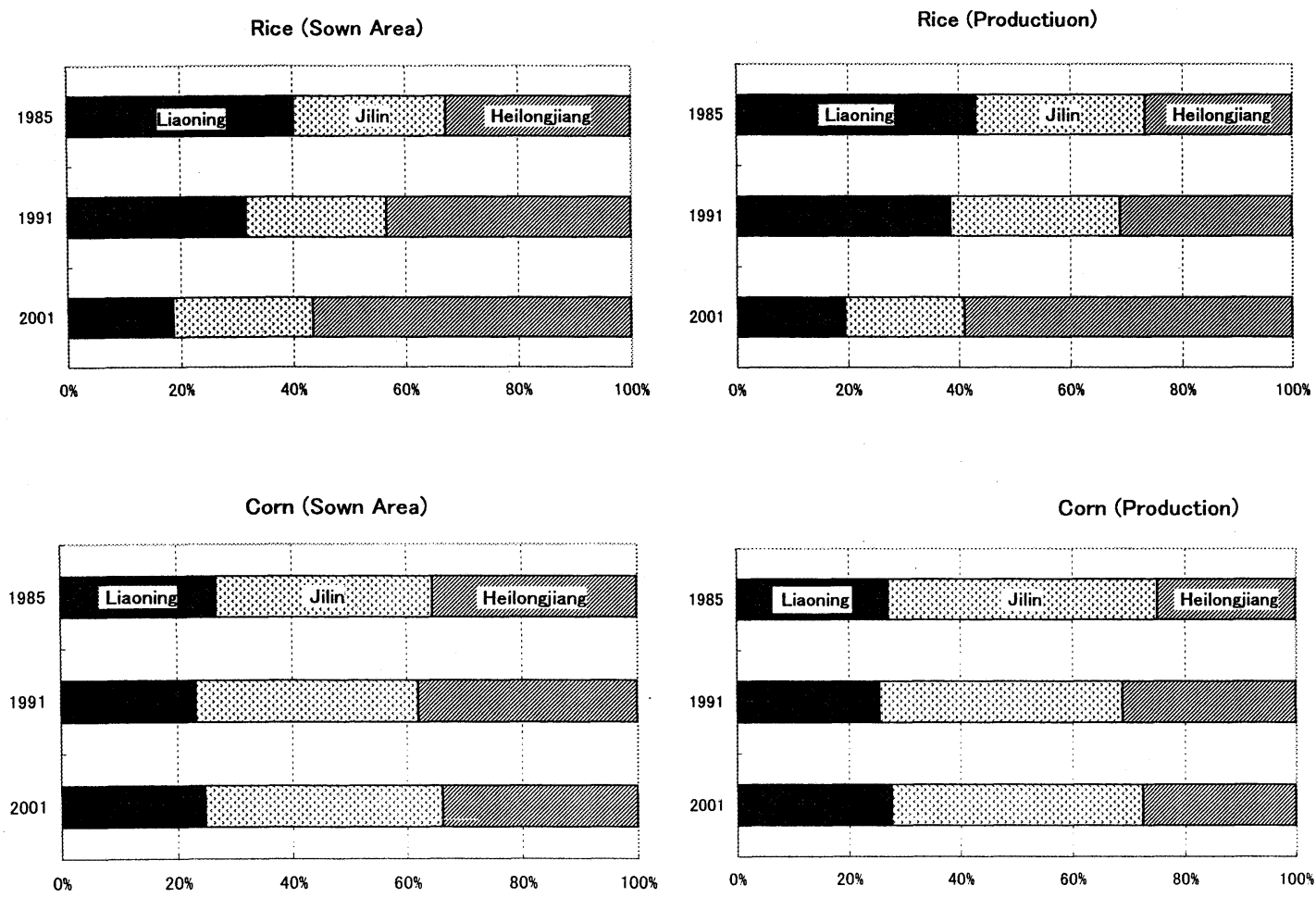

Figure 4. Change in the regional composition for the case of rice and corn.

corn and bean distributed in limited areas along the eastern edge of the northeastern plain (at the western foot of the Changbai mountain range), across from Liaoning and Jilin to Heilongjiang. Although that was true until around 1985, this relationship between the south and the north has now greatly altered things.

Figure 5 refers to the local development of rice production in the Northeast and is based on data provided by the city and county. Rice is widely grown (paddy rice production) in the lowlands of Liao River (Liaoning Province), Songhua River (Jilin Province) and Nen and Songhua Rivers (Heilongjiang Province).

With a few exceptions, the neighborhood of Changchun of Jilin Province was regarded as the limit for rice growing in the 1930s (Minamimansyu Tetudo Kabushikikaisha Chihobu Nomuka 1937: 184). However, we can today see many instances of rice cultivation in the Northeast beyond this line, further to the north. At the same time, we should bear in mind that rice cultivation also spread from the east to the west. Though the extension of rice growing to the north word means moving to colder areas climatically, and to the west it involved arid land, I want to emphasize that, broadly speaking, we should think of both dimensions when talking about the development of rice growing today.

From the view point of economic geography, it is a regional differentiation of rice production due to urbanization or industrialization. The next section will examine how such a phenomenon of rice growing has been realized locally.

\section{Field Survey of the Rice Frontier in the Songnen Plain}

\section{Research area}

Although the Sanjiang plain, located in the lower reaches of Songhua River, can be regarded as the frontier of rice growing in the Northeast, field research was carried out for the so-called Songnen Plain ${ }^{6}$ extending from the northwest of Jilin Province to the center of Heilongjiang Province, because of typical characteristics of a rice frontier to be expected in an 


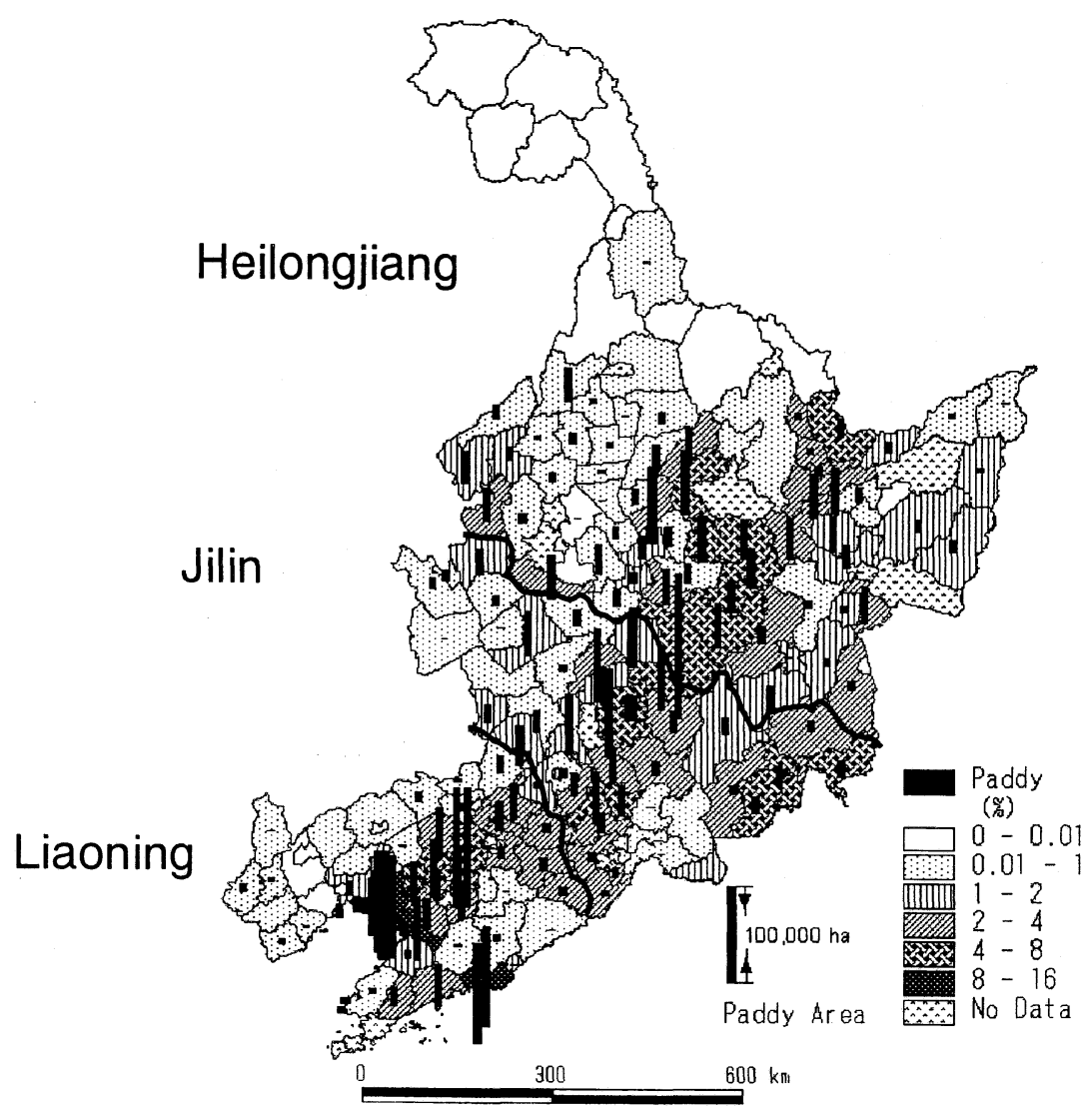

Figure 5. Distribution of paddy rice cultivation areas in the Northeast China (1997).

inland area.

Two representative examples are investigated: cold districts with wetland and alkaline soil areas with wetland (Figure 6).

The first example refers to the cities of Shuihua and Hailun located in the central part of Heilongjiang Province, to the western foot of the Small Xinganling mountain range and to the north of the provincial capital, Harbin. According to facts given by the local government office, total paddy field acreage for rice in both cities extends to an area of 600,000-700,000 $\mathrm{mu}$ (about 40,000 to $46,666 \mathrm{ha}$ ), and ranks among the first three in Heilongjiang, after Wuchang with $700,000-800,000 \mathrm{mu}(46,666-53,333 \mathrm{ha})$ and Sanjiang plain with $800,000-900,000 \mathrm{mu}$ $(53,333-60,000 \mathrm{ha})$. This district is also one of the 50 food bases which have been nominated by the national government since 1983 .

The second example is Da'an City and Qianguo County nearby, in the northwestern part of Jilin Province where the Nen River joins the
Songhua River. Both areas lie within the frontier of rice growing in the same province, although rice growing within Jilin province is still of minor importance. Geographically speaking, Suihua City and Hailun City are located north of Qianguo County and Da'an. The former is blessed with a good agricultural climate, while the latter suffers from semi-arid conditions and is also in the center of an alkali soil zone.

Therefore, the rice growing frontier expands toward the semi-arid and low swamp region developed on both sides of the Nen River (left bank in Heilongjiang Province, right bank in Jilin Province), from the wavy plain at the western foot of the Small Xinganling Mountains on the Heilongjiang side.

\section{Some aspects of the rice growing region}

Paddy field construction and rice cultivation in cold climate (Hailun City) Hailun City, located in the northeasternmost end of the 


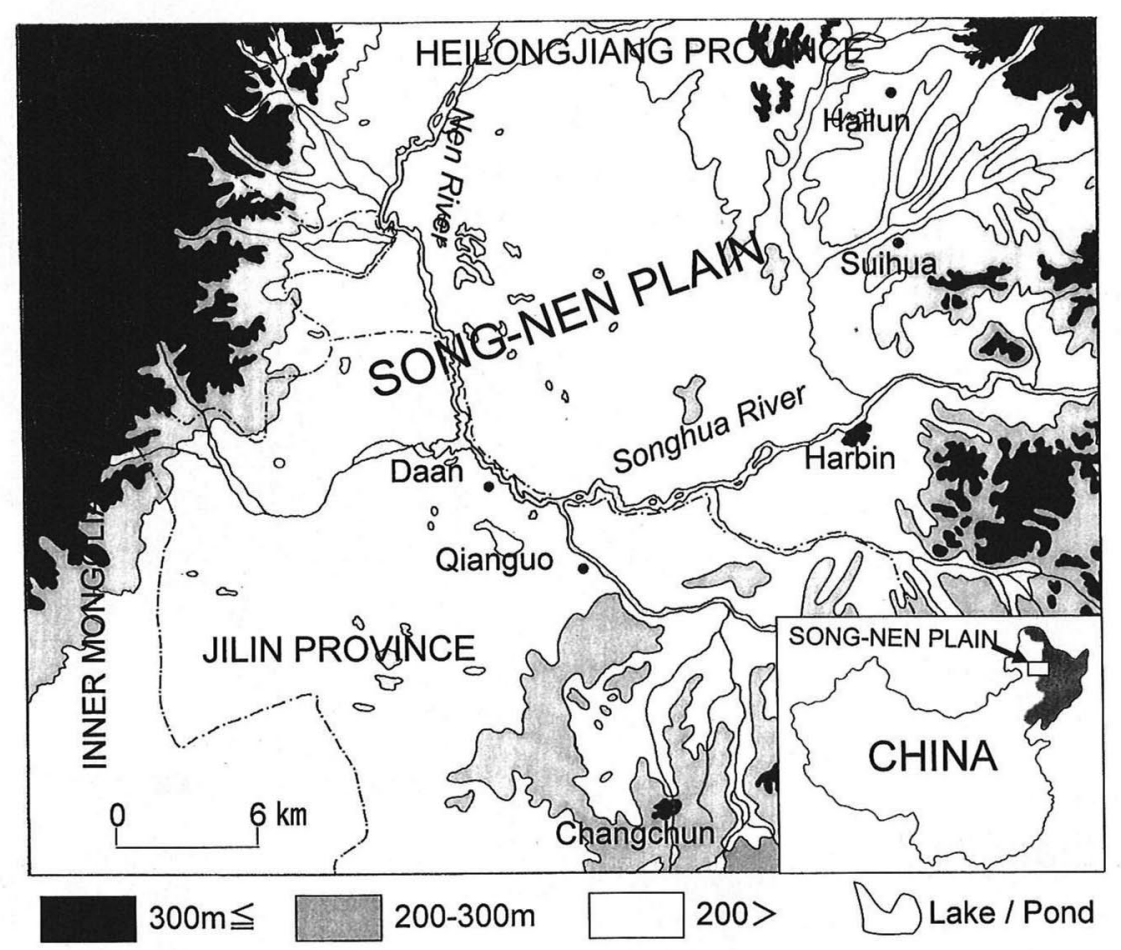

Figure 6. Research area-Songnen Plain-.

Songnen plain, has a land area of $4,675 \mathrm{~km}^{2}$ and a population of 790,000 . The northeastern side within the region is high, and some rivers are located in the southwestern corner in lower land. Although the annual mean temperature is $1.2^{\circ} \mathrm{C}$, the annual difference is large: it can fall to $-22.6^{\circ} \mathrm{C}$ in January and go up to $21.4^{\circ} \mathrm{C}$ in July; the average frostless season stretches over 118 days. Precipitation increases from the southwest towards the northeast, and forests and prairies are interwoven with each other. The area used for paddy rice in Hailun City comprises about $25 \%$ of the total arable land area $(250,000 \mathrm{ha})$, which is around 30,000 ha.

To the southwest of the Small Xinganling mountain range, a geographical feature resembling a wave and a plateau emerges. Golden paddy fields stretch over low land and are surrounded by dry fields, which makes for a very impressive landscape. We noticed colonial settlements in this area, both near the top part and near lower lying parts; the former settlements were by the Han tribe, the latter by Koreans. Otherwise unused swampy ground served for developing paddy fields in the lower areas. Ac- cording to the information obtained, paddy field developments were started by Koreans before World War II and then developed by the Han tribe. As such areas were developed, some kind of governmental treatment was granted: land-use rights for 50 years and preferential tax-rates for farmers reclaiming land (Imai 1998).

What greatly influenced the development of rice fields in this area, was Japanese rice growing technology, especially the introduction of the "Hatanae method" which is a method of nursing rice on a dry seedbed. This experiment was carried out by Mr. Hara Shoichi who came to this city (Dongtai-cun) after his retirement in 1982; he came from the Hokkaido National Agricultural Experimental Station in Japan and began technical instruction. The paddy field areas of Hailun City in those days amounted to $0.7 \%$ of all arable land and extended over 1,780 ha; it yielded $210 \mathrm{~kg}$ per 10 ares (brown rice) according to Hara (1999). But this yield turned into about $470 \mathrm{~kg} / 10$ a in 1998 , while paddy fields occupied about $1 / 4$ of all arable land. The city thus became self-supporting in rice. $\mathrm{He}$ 
described this effect as follows: "When I visited the place in 1982 wheat was the staple food in Heilongjiang. Even if because of a lack of rain, production decreased, wheat was still ordered to be planted. But then I noticed during a visit in 1998 that the staple food had changed to rice in Heilongjiang, the dependence on wheat decreased, and corn for export to Japan increased" (Hara 1999: 9).

The following fact may open up new possibilities for future rice crop farming: we observed at the Agro-ecological Experiment Station of the Chinese Academy of Sciences in Hailun new trends when examining dry fields (Photo 1) and we found a Japanese variety of high quality rice since 2000 . A paddy field was built in the area using groundwater $(80 \mathrm{~m})$, and the Hoshinoyume variety was introduced from Hokkaido, Japan.

Let's now look at the present conditions of rice growing at Dongtai village where Mr. Hara started the introduction of rice growing technology. This is what Mr. Cui Zhong-yi (56) and Mrs. Cui Yong-zhu (51) say: although this village consists of 135 households (700 persons), $85 \%$ of the residents are Koreans. The arable land area is $4,500 \mathrm{mu}$ ( $300 \mathrm{ha}$ ), with around 6 mu (0.4a) managed per person. The Han families resided in the hilly part, whereas Koreans lived in the lowlands in 1910 (Photo 2). This is how the exploitation of the surroundings started. Although paddy-field enlargement has been seen in part since 1940, drainage and spade-work were difficult and did not develop much, so that about $90 \%$ of the lowland was left as a pond or a grass-area. Paddy-field development started after Mr. Hara's visit in 1983 when he gave technical instruction on rice crop farming. In this village, paddy fields of 300 or more mu were already in existence, and more recently the Han tribe also acquired paddyfields in lowlands. There is now no more room for developing new paddy fields. Although eight rice planting machines were introduced at the beginning, there is sufficient labor force in the villages, and since the production costs soared while rice prices fell in recent years, another two sets are now needed.

The main rice crop being planted in this area is Hejiang No. 19 (Jiamusi), in addition to gluti-

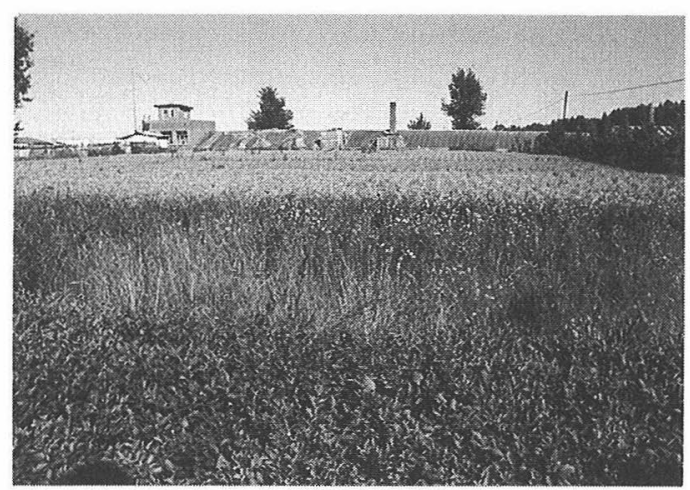

Photo 1. Test site of paddy rice at the Agroecological Experiment Station of Chinese Academy of Sciences (Sept. 2000, at Hailun, Heilongjiang Province).

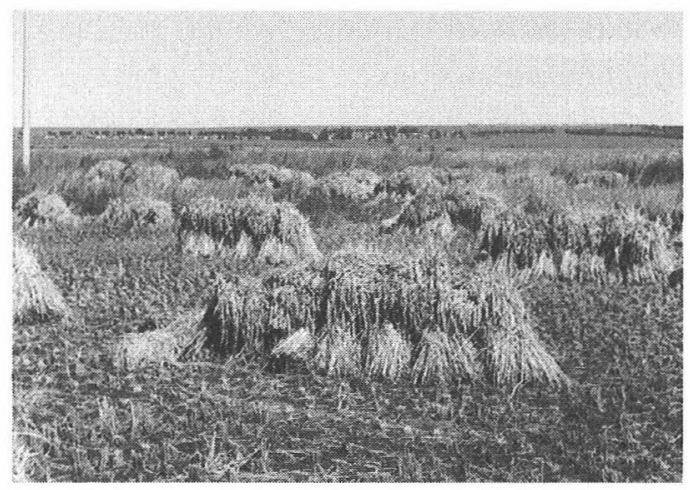

Photo 2. Korean peaple's paddy fields spreading at alluvial lowland (foreward) and Han's settlement with upland field (backward) (Sept. 2000, at Dongtai-cun Hailun, Heilongjiang Province).

nous rice (2-3\%). Rice planting takes place from May 15 to 17, harvesting around September 12 to 15 . The temperature at the time of rice planting is $12-15^{\circ} \mathrm{C}$. Irrigation is mainly from river-water, although some ground water is also used. Through this method, the yield which used to be about $300 \mathrm{~kg} / 10$ a before $\mathrm{Mr}$. Hara's technical instruction, has now attained $400-500 \mathrm{~kg} / 10 \mathrm{a}$. A profit per 10 a of roughly RMB 2,000 yuan is aimed at, while production costs amount to around RMB 1,000 yuan. The main production costs include chemical fertilizer and agricultural chemicals (12-15\%), labor expenses, the cost of machinery (40\%), irrigation water supply (40\%), etc. 
As living conditions for farmers have improved in this village, telephone and television were virtually non-existent during a visit to Dongtai-cun (Village) 15 years ago but nowadays color TV is quite common. About $40 \%$ of the colony consists of new buildings (which may cost anything between RMB 5 to 7 million), and two-story buildings can also be found. However, the improvement in living conditions cannot really be regarded as the result of rice crop development. In fact, 70 or more persons in these villages are receiving contributions from emigrants to other economic zones in China, or to foreign countries like Korea, Japan, Singapore, Spain, Russia, etc.

Also, the average size of families, which used to be about seven persons, is now decreasing to 3 or 4 persons. Although under the Chinese one-child policy, Korean families here can have two children, they usually have just one child. The main reason are higher school-fees. As a result, although there were 150 school- children 20 years ago, the size of the school has now shrunk to just 12 pupils. We can therefore also anticipate a problem of a labor shortage in the future, which will also affect the rice cultivation. Although farms managing $100 \mathrm{mu}(6.7 \mathrm{ha})$ of the rice have appeared, they are still rare. Mechanization and the improvement of the land infrastructure will greatly influence the future of rice crops.

Rice farming leading to high quality rice in Suihua City Suihua City is located on the eastern border of the Songnen plain, which has an area of $2,743 \mathrm{~km}^{2}$ and a population of 801,000 people. A branch of the small Xinganling mountain range extends along the northeast, and, as for topographical features, the region consists of high-land, while the southwest is low-land with many rivers. Although the annual mean temperature is $2.2^{\circ} \mathrm{C}$; there is a huge difference in temperature with $-21.4^{\circ} \mathrm{C}$ in January and $22^{\circ} \mathrm{C}$ in July. Precipitation in summer is around $523 \mathrm{~mm}$ in July and the non-frost period extends to 128 days.

The present paddy-field areas there reach 40,000 ha, and more than half of the 27 administrative units (Xiang/Zhen) within the city grow paddy rice. Except for the Xinghe-xiang paddy field which was established in the 1930s, most places were only developed recently, although there were originally quite a number of damp areas and dry fields. Rice crops reached $83 \%$ of the paddy rice surface area and the Hatanae method was introduced in 1983.

A further study of rice farming in Shuanghezhen reveals the following: Although a paddyfield of 700 ha was formerly established in the Shuanghe-zhen People's commune, it has now expanded to 5,000 ha. In the case of Ronhuacun (village) in Shuanghe-zhen, all 400 households are carrying out rice paddy cultivation. This village was typical for this area: a newly constructed storehouse, a splendid building for rice seeds, a deep drainage canal, square paddyfields with ears rising upwards due to dryness, traditional roads in need of repair.

In such landscapes, the spectacle of husband and wife engaging in mowing was quite impressive. Mr. Wang, 51 years old, is a farmer who manages paddy fields of $44 \mathrm{mu}$ ( $2.9 \mathrm{ha}$ ) together with his wife, daughter and her husband. He is a so-called 'rice monoculture farmer' who converted dry fields after the demolition of the People's commune. The type of rice cultivated is mainly non-glutinous rice, while only about ten percent of the growing area is devoted to glutinous rice, which is more expensive. For reference, his family's present everyday diet has greatly changed from wheat and millet in the past to three daily portions of rice.

With natural irrigation a crop production of $400-500 \mathrm{~kg} / 10$ a can be achieved. This is double the result of the time of community production when $200-250 \mathrm{~kg} / 10$ a were harvested. The income is roughly RMB 4,000-5,000 yuan per 10 a while around RMB 2,000 yuan are used for production cost, such as agricultural chemicals, chemical fertilizer, seeds, main wages, etc. While-thanks to water-saving technologythe cost of water decreased, the price of chemical fertilizer increased suddenly.

It is noteworthy within the city that the various stages of paddy field improvement led to higher productivity or better rice quality. Photo 3 shows the signboard at Qinjia-zhen which explains the method used by the Agricultural Technology Institute established in Heilongjiang Province. We can notice that their method comes close to the Japanese 


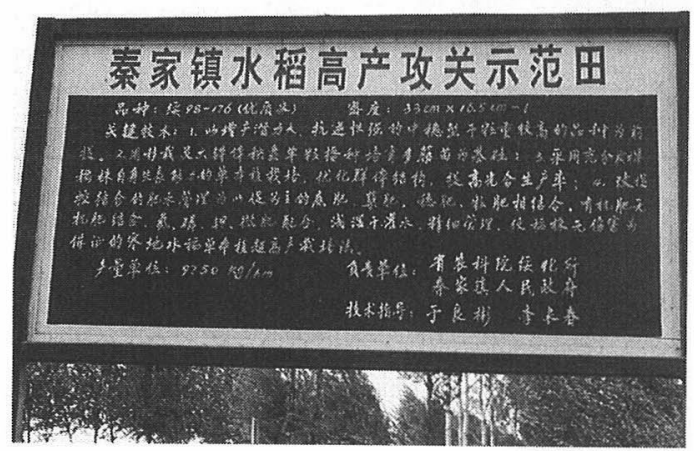

Photo 3. Signboard which explains the new method for rice (Sept. 2000, at Qinjia-zhen, Shuihua, Heilongjiang Province).

method, which was established and proven in the colder regions of Northern Japan. A variety of techniques were used: a newly developed crop type with stronger resistance to cold weather; a combination of nitrogen, phosphoric acid, and potash (organic and inorganic), irrigation water management, etc. Xinhe-xiang is, according to Mr. Jin Jian-hua, the vice-president for agriculture of this province, an example of a rice crop development that started in 1984 and at present stretches over $20,000 \mathrm{mu}$ (1,333 ha). Here the Japanese variety called Fujihikari makes up $60 \%(12,000 \mathrm{mu}=800 \mathrm{ha})$ of the land.

Finally I would like to make a few remarks on today's rice cultivation. According to what we heard from the Agricultural Institute of the City, the annual income amounts to about RMB 10,000 yuan per farm now. While about RMB 2,000-2,700 yuan of this income is derived from rice crop sales (agricultural income), the revenue from non-agricultural sources is about five to six times as much. To sustain the cultivation of rice, a relatively high price is necessary. But recently - since 1997-prices have tended to fall. Although rice was worth RMB 1.2 yuan per $500 \mathrm{~g}$ in 1996 , the free market now only offers about half that price, between RMB 0.5-0.7 yuan. Whereas the national purchase price changed little, it also started falling in 1996 from RMB 0.6 to 0.57 yuan.

Under these conditions, the farmers have changed to higher management crops, or otherwise work away from home as rice cultivation loses its profitability. Subsequently the overall population seems to have shrunk on quite a large scale through emigration. Although increased mechanization could be used to make up for labor shortage, the fact that most of the emigrants are younger people makes this rather difficult. Moreover, since ground maintenance has not been completed, heavy machinery is not suitable for peat bogs as it starts sinking. If mechanization is to be further introduced, national or provincial assistance is indispensable.

Paddy field improvement and development by flood control or the use of water from Nen river in Qianguo County Qianguo county belongs to Jilin Province and is located in the southwest near the convergence of the Songhua and the Nen Rivers. This county stretches over a total area of $7,076 \mathrm{~km}^{2}$ and has a total population of 536,000 with 19 tribes such as Mongol, Han, Hui, Korean, and Shibo. It begins on the outskirts, and many small ponds or lakes are located in the area. This is where Chagan Lake is, which is one of the ten major freshwater lakes in China.

Although the climate is dry in this area, we find a vast wetland mainly formed by the flooding of the Nen River with plenty of fresh water. We can expect vast rice zones here if the real river can be maintained and water supply works have been carried out.

As an example we can look at Tafuchang whose construction began in 1987 and was completed in June, 1997. A total investment of RMB 6,958,000 yuan had been made for by the city and the provincial financial office, and 60,000 workers were hired. As a result, a total irrigation area for paddy fields of $31,300 \mathrm{mu}$ ( 2,087 ha) was created (Photo 4). Moreover, the low productivity paddy fields of $20,000 \mathrm{mu}$ (1,333 ha) were improved by an investment of RMB 5,490,000 between August, 1999 and May, 2000. At the time of investigation, repair-work at the river-bank after the flooding in 1998 had made good progress, and there were signs of a new irrigation water supply construction in the area at the passage from Jilin to Heilongjiang. We could also see the agricultural comprehensive development project at a national level which started on July 25,2000 and was completed on October 30,2000 . This project consists of the construction of a dam for flood- 


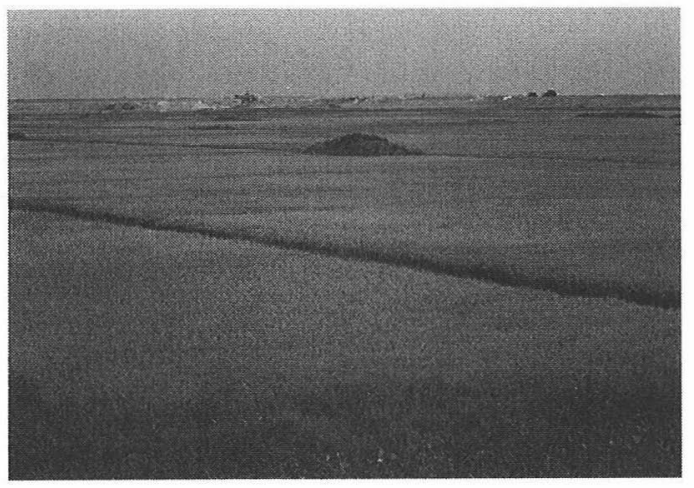

Photo 4. Construction of embankment for flood-prevention and newly developed paddy fields (Sept. 2000, at Qinguo County, Jilin Province).

prevention within $4.3 \mathrm{~km}$ inside Qianguo County and thus represents a large-scale water irrigation project.

Construction of paddy-fields in the alkaline soil zone: Da'an City Da'an City, which is situated in the northwestern part of Jilin Province and the centre of Songnen plain, boasts a population of about 420,000 people made up of eight tribes such as Han, Man, Hui, and Koreans. The region gets little precipitation with about 400 $\mathrm{mm}$ per year (except $700 \mathrm{~mm}$ in 1998) so that drought poses a problem. The land is generally flat (120-170 $\mathrm{m}$ above sea-level) with many small lakes and ponds. Alkaline soil is predominant: the alkali area occupies $59 \%\left(2,880 \mathrm{~km}^{2}\right)$ of the total surface of Da'an City $\left(4,913 \mathrm{~km}^{2}\right)$.

Although there are some rivers such as the Nen, Erhe or Huolinhe Rivers, these were not used for irrigation of farmland. The area is generally characterized by grassy or unused places land that could be widely developed. Land productivity was very low until 1990.

Under these circumstances, paddy rice cultivation was first initiated at Shagan-zhen in 1989 by the Changchun Geographical Research Institute of the Chinese Academy of Sciences which set up a test site: paddy rice was planted and more and more paddy fields were set up in various places. At present $100,000 \mathrm{mu}(6,666$ ha) are covered by paddy fields and a future increase to $210,000 \mathrm{mu}(14,000 \mathrm{ha})$ is expected.

According to an explanation by the Agricultural Office of Da'an City, the irrigation resources for the present paddy fields are split up in the following proportion: Erhe River 7 parts, Nen River 2 parts, and groundwater 1 part. Although the water supply development of Nen River is not crucial here, it is expected to become more important in the future.

According to the material in the Da'an agriculture technological model district where the above-mentioned Changchun Geography Institute is located, factors that prevent agricultural development in this region are damage caused by drought, flood, and alkalization. Here comprehensive water improvement measures were taken: extraction of salt from damp alkali soil to prevent the alkalization of rice; measures to prevent floods; the improvement of sandy and dry land with water-saving irrigation technology; or the use of ponds for further cultivation. This led to the creation of an area of $30,000 \mathrm{mu}$ $(2,000 \mathrm{ha})$ for experimental purposes, 150,000 $\mathrm{mu}(10,000 \mathrm{ha})$ became the model area and various technologies were used over an area of $1,420,000 \mathrm{mu}$ (about $95,000 \mathrm{ha}$ ).

Although an average of $25 \%$ of the production increase target is used to improve the actual paddy rice production in alkali soil, the accumulated result over four years reaches $2,700 \mathrm{~kg}$ and the total production amounts to RMB 35,100,000 yuan. Rice cultivation in alkali ground has made an important contribution to the life of the farm village and its economy.

The following example case was observed: The farmers who developed paddy fields are doing so under a contract of 2 ha per household of four persons (Photo 5). Their rice season

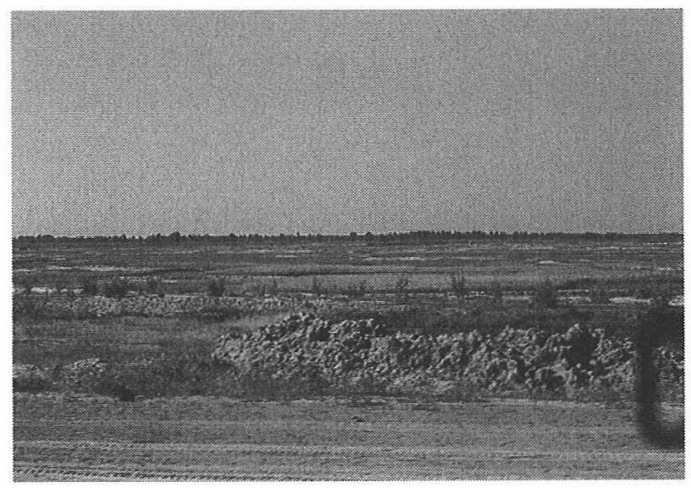

Photo 5. Newly developed paddy fields at the alkalized lowland (Sept. 2000, at Da'an City). 
stretches from rice planting at the end of May to harvesting at the end of September. The farming families stressed that while in former times they only had rice on special occasions such as the Spring Festival, they can now eat rice regularly, and that they still had strong future expectations for rice. They mentioned the problem of water resources: at present they were dependent on ground water with a low temperature but they hoped that in future they would have access to river-water, namely, from the Nen River.

Finally we can conclude that by using technology, such as scientific irrigation and soil improvement, the alkali ground as the foundation for development of rice paddies has continuously hardened. Also, I would like to add that this technological progress was brought about with the contribution of the Japanese Ministry of Agriculture, Forestry and Fisheries, with rice paddy specialists of the Northeast Agricultural Experimental Stations in Japan, and with other international assistance and cooperation from the United States and Australia.

\section{Factors that promote and restrain rice culti- vation}

Against the background of today's rice production in the Northeast, we can find several new factors that promoted this development. But there are also a few factors that restrained further development. As rice production has now become a major axis of change as far as the use of land is concerned, I would like to elaborate on factors that promote or restrict progress (Table 4).

What first attracted most attention as a promotional factor is the fact that rice crop technology could spread in a colder region. Huang and Luo (1996) attribute $96 \%$ of this to techni-

Table 4. Some major factors influencing the rice culture in Songnen plain

\begin{tabular}{|c|c|c|}
\hline Type & Promoting factors & Restricting factors \\
\hline \multirow{6}{*}{$\begin{array}{c}\text { I } \\
\text { Northeastern Part of } \\
\text { Songnen Plain } \\
\text { (Suihua and Hailun) }\end{array}$} & $\begin{array}{l}\text { Introduction of Japanese style rice } \\
\text { culture technology for cold district }\end{array}$ & $\begin{array}{l}\text { Environmental problems as massive } \\
\text { usage of agricultural chemicals }\end{array}$ \\
\hline & $\begin{array}{l}\text { Techniques of high-yield and high } \\
\text { quality of rice production }\end{array}$ & $\begin{array}{l}\text { Growing expectations for profitable } \\
\text { cash crops }\end{array}$ \\
\hline & $\begin{array}{l}\text { Progress of water saving rice culture } \\
\text { techniques }\end{array}$ & $\begin{array}{l}\text { Inadequately prepared paddy fields for } \\
\text { using agricultural machines }\end{array}$ \\
\hline & Existence of the rural labor force & $\begin{array}{l}\text { Outflow of the rural labor force } \\
\text { (Korean) }\end{array}$ \\
\hline & $\begin{array}{l}\text { Rice selling to domestic and export } \\
\text { market }\end{array}$ & $\begin{array}{l}\text { Traditional marketing channel of rice } \\
\text { and distant place from main rice } \\
\text { demand area }\end{array}$ \\
\hline & Government policy of rice price & Government policy of rice price \\
\hline \multirow{6}{*}{$\begin{array}{c}\text { II } \\
\text { Central and } \\
\text { Southwestern Part of } \\
\text { Songnen Plain } \\
\text { (Qianguo and Da'an) }\end{array}$} & $\begin{array}{l}\text { Progress in the flood control of the } \\
\text { Nen river and in the } \\
\text { irrigation facilities works }\end{array}$ & $\begin{array}{l}\text { Difficulty to invest farmer's money in } \\
\text { agricultural land }\end{array}$ \\
\hline & $\begin{array}{l}\text { Exploitation and utilization of the } \\
\text { abundant ground water }\end{array}$ & $\begin{array}{l}\text { Environmental problem due to over } \\
\text { use of groundwater }\end{array}$ \\
\hline & $\begin{array}{l}\text { Water saving technology for rice } \\
\text { cultivation }\end{array}$ & $\begin{array}{l}\text { Development of fish culture in low- } \\
\text { lying saline-alkaline land }\end{array}$ \\
\hline & $\begin{array}{l}\text { Improvement of the landuse system in } \\
\text { saline-alkaline land area }\end{array}$ & Irrigation water shortage \\
\hline & $\begin{array}{l}\text { Increasing rice consumption within the } \\
\text { region }\end{array}$ & - \\
\hline & Government policy of rice price & Government policy of rice price \\
\hline
\end{tabular}


Table 5. Percentage of the improved land of alkalized agricultural land

\begin{tabular}{ll}
\hline Heilongjiang Province & 34.7 \\
Jilin Province & 49.5 \\
Liaoning Province & 85.6 \\
All China & 72.7 \\
\hline
\end{tabular}

Source: China Statistical Yearbook, 1999.

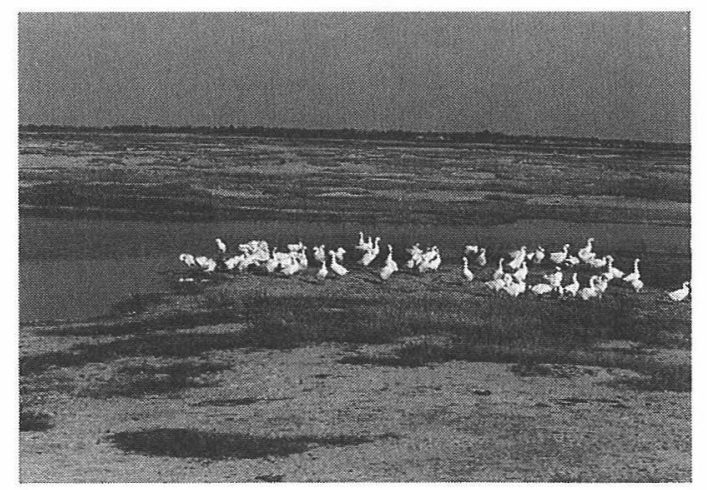

Photo 6. Potential of rice production in alkalized area (Sept. 2000, Da'an City).

cal progress and it seems that technical progress during a period of reform from 1984 to 1992 contributed, indeed, to the increase in production. It should further be added that the technology begun by Mr. Hara-namely the method of raising seedlings in dry fields - was established in the colder districts of Japan and was also a very positive contribution. Moreover, we may assume that, in future, the technology of rice crop development in alkaline soil will further spread in the Northeast.

Table 5 illustrates how the Northeast still lags somewhat behind in the use of alkaline farmland but also points at the hidden possibilities of rice production in that area (Photo 6). Furthermore, we cannot say with certainty whether the development of rice crop in recent years is simply the result of improved technology, or whether factors such as the general warming of the climate also contributed to this success (Fang and Sheng 2000). In addition to socio-economic factors, the role of the price policy plays may be even more important than the production responsibility system (privatization). Together with the efforts for self-support in food, rice has also raised the awareness for reorganized management as people become concerned about groundwater development and the condition of rivers.

Much of the western marshy grassland in the inland region of the Northeast which is fed by flood waters of some rivers, has served as the historical grassland of the minority herders for grazing cattle, sheep, horses, etc.. The green manure cropping system here has been generalized as an indigenous land use system. But after the implementation of reforms these historical land use systems were replaced with cash crops, which led to a rapid decline in the overall soil quality. As a result, crop rotation was simply abandoned throughout Heilongjiang in favour of monoculture, with the choice of crop (especially corn) depending on short term profitability (Muldavin 1997). This phenomenon of resource degradation can be widely found in marginal areas in China but fortunately few problems have arisen in this respect in the case of paddy-fields.

Factors restraining rice crops exist inside and outside agriculture. My report on Jilin province (Motoki 2000) also raised this point, but I would simply like to mention factors such as urbanization, increased road maintenance, and trading of high value crops with greater profitability, which all restrict further rice cultivation and contribute to the localization of rice crops. We must equally bear in mind that water shortage is a major limiting factor in regions such as the southern part of the Northeast where water is transferred from the agricultural sector to the industrial base (Dazhong and David 1992).

Yet in the whole of the Northeast, the most unknown factor may well be the market price of rice in the future. And this has been mentioned as a central issue in the case of rice cultivation in Heilongjiang, which recently experienced a drop in rice production (Murata 2000). Murata's investigation has also made clear that future labor shortage may be a matter of concern as well. There is a marked outflow of workers from a village mentioned with a strong Korean population (for example, see Zheng 1999). Although it may be argued that large-scale rice crop management can overcome these difficulties, mechanization and problems of land maintenance still have not been solved. 


\section{Conclusion}

There is a tendency of allocating less land to agriculture and thus food crops in China, which has become quite obvious in the process of the past 20 years of economic reforms. But this is not an even trend throughout the whole country. As for northern China, its importance as a food production area is rising. Although the fundamental land use situation in China (wheat in the north, rice in the south) is still intact, priorities in food production in the north and the south are shifting. Moreover, the spread of rice cultivation to the north becomes apparent, while the south - a historically important ricegrowing region-is showing signs of decreasing rice-farming, a point this paper paid much attention to. Due to the rice growing development in northern China, especially in the Northeast, rice consumption there grew in favour of traditional food crops. Cash crop development in dry fields was encouraged, and there are possibilities of export to foreign markets.

Apart from the rice growing development in the Northeast, we have to consider technological developments in land productivity. Labor productivity due to mechanization will be another important topic. When comparing with trends in Japan, South Korea, Taiwan, etc., rice growing in China will mostly benefit from managerial reorganization. As the economic reforms enforced land use changes caused by industrialization and urbanization, we can assume that the major future changes will be made on the managerial and technical side.

In addition to this, the areal differentiation phenomenon (especially the expansion northwards) of the so-called Japonica type of rice in China assumes a different meaning from what Japan experienced with the Japonica type in the past. Although Indica rice was predominantly planted in China, Japonica rice has led to new developments in rice planting areas. From the supply side, rice consumption not only increased in the Northeast, but also plays an important role in the rest of northern China, especially in large cities such as Beijing and Tianjin. This is because Japonica rice used to be the prevalent variety in this area before recent, in- dustrialization and urbanization caused rice cultivation to diminish. ${ }^{7}$

After a possible conversion from Indica to Japonica in areas where rice consumption is dominant (in the lower regions of the Changjiang River), Japonica may lead to rice cultivation of superior quality in the Northeast. The rapid development of rice growing in the Northeast after the reforms as outlined in this paper, not only contributed to geographical differentiation but may also exert its influence on rice cultivation in the south, or in other words, it presents a hypothetical challenge from the north to the south. Furthermore, the recently grown high quality Japonica rice has the possibility of being exported to neighbouring countries such as Japan, Korea and Taiwan.

Of course this does not necessarily have to happen in the future. China will not resort to a high price policy as was done in Japan and South Korea, and since China joined the WTO it will have to restrict the domestic protection policy of the rice price. At any rate, it will be very important to see what policy the Chinese government will follow in the rice issue as it can have large repercussions on the area, not only on a domestic scale but also internationally. As Brown also says it will be a decision on 'Who Will Feed China?'

\section{Acknowledgments}

A part of this paper was presented at the spring meeting of the Tohoku Geography Association in 2001. As far as the field survey for this research is concerned, I am greatly indebted to Dr. Zhang Bai from the Changchun Geography Research Institute of the Chinese Academy of Sciences as well as to a number of staff of this institute. I also benefited from the help of governmental agencies at every place, from experimental research institutes, and from many farmers. My special gratitude goes to Professor Yukio Himiyama of the Hokkaido University of Education who conducted the survey from beginning to end. I also wish to thank Dr. Kuninori Otsubo as the representative of the LU/GEC project.

(Received 15 October 2003) (Accepted 31 July 2004)

\section{Notes}

1. The LUCC (Land Use Cover Change) Programme of the world starts in 1996. IGU (Inter- 
national Geographical Union) set up a Study Group on LUCC in the same year with Dr. Himiyama as its chair. The LU/GEC (Land Use for Global Environmental Conservation) Project was initiated in 1995 by Natioual Iustitute for Environmental Studies, Environmentl Agency of Japan. Special attention was paid to Chinese land use trends in these programmes.

2. The fundamental principles of the LUCC (Land Use/Cover Change) Programme are similar in that point.

3. Zhang (2000) does interesting research on the trends of Chinese food production, taking into account the regional situation. His study is helpful although it does not give a general outline and does not cover the problem of rice.

4. Millet has an evaporation coefficient half of that of wheat and is not very resistant to alkaline soil. Kaoliang has half the leaf surface if compared with corn, but a root twice as long. Therefore, both crops easily adapted to dry areas of the northern part, or even to areas exposed to flooding.

5. The technology of $F_{1}$ hybrid rice was established by a Chinese scientist, Yuan Long-ping, in 1976. He mentions the advantages and disadvantages as follows: "In the past we had great food shortages, so this is a good change. But now we have overproduction, rice is stored all over the place, and we're changing our strategy to keep the yield high but improve the quality. Too bad the government won't give us as much research money as before" (White 1994).

6. This investigation was conducted for the area of Songnen plain over the central part of Heilongjiang from the northwestern part of Jilin during the period of September 15-20, 2000. For observing the actual conditions of development in the north, the selection of the investigation area proved very appropriate. The investigation started in Changchun, Jilin, continued to Songhua River further in the northwestern part of the Province, and then went on to the central part of Heilongjiang.

Road and bridge maintenance work was carried out and commercialization touched the farm villages in every place of this investigation. Signs advertising agricultural projects or model areas were widely encountered.

There was, for example, a sign for a model site for irrigation and water-saving, a model site for corn cultivation, for agricultural selfsufficiency, for water supply items, improvement of low-productivity land, onion production bases, a model site for a high-productivity paddy field, for the market of agricultural products, the wholesale market, a model site for national corn seed, melon production base, etc.
All this stands for change in local agriculture. Moreover, colorful cultivations of crops, corn, paddy rice, soybeans, huangmi, kaoliang, egg plants, onions, Chinese cabbage, burdock, watermelons, potatoes, sunflowers, tobacco, etc. were visible in several places. It seemed that cash crops increased in number, crop rotation of corn and soybean was carried out as well as intercropping between soybean and corn in drier fields. Single cropping was mainly performed in the paddy fields. However, wheat was produced in low quantities. Land was mainly used for the production of grain and rice as I pointed out in the preceding chapter, i.e. corn and soybean in dry fields and rice in paddy fields.

7. According to the recent report (Brown et al 2000: 71), underground water in the North China Plain-an important cereal production area-declines by about 1.1-1.5 m year by year, but demand for water is on the increase. In order to respond to this difficult situation, China may have to give up irrigation agriculture, change to crops which can be grown with comparatively little water, or improve irrigation efficiency. All this will have a big influence on future cereal production in China.

\section{References}

Bishop, C. W. 1922. The geographical factor in the development of Chinese civilization. Geographical Review 12 (1): 19-41.

Bito, A. 2000. The Framework of Land Use and Land Cover Change Programme (LUCC) and Related Projects. Journal of Geography 109(3): 346-365. (J)

Brown, L. R. 1995. Who Will Feed China? New York: Norton.

Brown L. R. et al. 2000. State of the World 2000-01. New York : Norton \& Co.

Buck, J. L. 1941. Land Utilization in China-1937 (Upper part). ed. Miwa and Kato. Tokyo: Seikatusha. (J)

Cai, Y. 1998. Land degradation in China: Status quo, impacts and countermeasures. In Making Regional Development in China Sustainable, Proceedings of the study program on urban development for China. ed. China Association for Science and Technology and United Nation's Center for Regional Development: 43-52.

Fang, X., and Sheng, J. 2000. Human adaptation to climate change: a case study of changes in paddy planting area in Heilongjiang province. Journal of Natural Resources 15(3): 213-217. (CE)

Hara, S. 1999. Chuugoku niokeru Inasaku-gijyutukyouryoku $17 \mathrm{ka}$ nen no Ayumi to Suitou-hatanaeishokusaibai no Kijyun /History of technical cooperation for rice cultivation in 17 years and the standard of Hatanae method (seedling and trans- 
planting) of rice paddy in China. Iwamizawa: Japan-China Agricultural Technical Exchange Iwamizawa Conference. $(\mathrm{J})$

$\mathrm{Hu}, \mathrm{Z}$. 1962. Relative high production district and its distribution of millet and Kaoliang in the North China plain. Journal of Beijing University 3: 286293.

Huang, J., and Luo, S. 1996. Potentiality, consumption, and trade in paddy rice-production in China. The China Rural Economy 4: 21-27. (C)

Huang, J., Rozelle, S., and Rosegrant, M. W. 1999. China's food economy to the twenty-first century: Supply, demand, and trade. Economic Development and Cultural Change 7 (4): 737-766.

Ikegami, A. 2002. Agriculture. In China Almanac, ed. Institute for China, 156-159, 303-306. (J)

Imai, M. 1998. Chuugoku Kokuryuukou-shou nioite Hata-nae-soshoku hou ga fukyuu shinntou suru Katei no Bunseki/Analysis of the diffusion process on the "hatanae" method of rice cultivation in Heilongjiang, China. The Aichi University Graduate School (China graduate course master paper). (J)

Lee, H. K. 1932. Korean migrants in Manchuria. Geographical Review 22(2): 196-204.

Li, X. Z., and Shi, Q. W. ed. 1988. General geography on the Northeast Economic Region. Changchun: Northeast Normal University Publisher. (C)

Lindert, P. H. 1999. The bad earth? China's soils and agricultural development since the 1930s. Economic Development and Cultural Change 47(4): 701 -736 .

Minami-mansyu-tetsudo Kabushikikaisha Sangyobu /Industrial part of Southern Manchuria Railroad Company. 1932. Mansyuu Keizai Soukan/An Overview of Manchurian Economy. (J)

Minami-mannsyu tetsudo Kabushikikaisha Chihobu Noumuka/Agricultural administrative section of Southern Manchurian Railroad Company. 1937. Mansyu no Suiden (Rice Paddy in Manchuria). (J)

Motoki, Y. 1997. Paddy field development in modern Japan: A development geography systems approach. Tokyo: Kokon Shoin. (J)

Motoki, Y. 1999. Chuugoku Tohoku-tiku no Inasaku Gaikan/An overview of rice culture in Northeastern China: Land use survey in south part of Northeastern China. In LU/GEC Project Report V, ed. K. Otubo: 99-109. National Institute for Environmental Studies, Environment Agency of Japan. (JE)

Motoki, Y. 2000. Kiturin-shou niokeru Nougyoutekitotiriyou no Keisei to Chiriteki-shojyouken/Recent agricultural land use and its geographical conditions in Jilin province, Northeastern China. In $L U / G E C$ Project Report VI, ed. K. Otubo: 99109. National Institute for Environmental Studies, Environment Agency of Japan. (JE)

Motoki, Y., and Bilaldin, N. 2003. The commercialization of lowland farming and its impact on the environment in the mountainous areas under economic reforms; A case study of Ghulja (Yining) county, Xinjiang Uighur autonomous region, China. Journal of Saitama University (Liberal Arts) 38(2): 157-182. (JE)

Muldavin, J. 1997. Environmental degradation in Heilongjiang: Policy reform and agrarian dynamics in China's new hybrid economy. Annals of the Association of American Geographers 87 (4): 579613.

Murata, T. 2000. SBS rice of Heilongjiang province, China. Nogyou oyobi Engei/Agriculture and Horticulture 75 (10): 1047-1048. (J)

Nakaya, T., and Shimizu, Y. 2002. A grid-surface projection of major grain comsunption in China. In Study on the processes and impact of landuse change in China. CGER: 51-59.

Otsubo, K. 2002. Toward sustainable land use in China-Highlight of LU/GEC phase II (Final report of the LU/GEC second phase, 1998-2000). Study on the processes and impact of landuse change in China. CGER: 1-15.

Rozelle, S., Veeck, G., and Huang, J. 1997. The impact of environmental degradation on grain production in China, 1975-1990. Economic Geography 73 (1): 44-66.

Sum, K. 1978. Japanese and Chinese agriculture: Comparison and appraisal. Science Reports of Tohoku University 7th Series (Geography) 28(2): 379385.

Wang, Y., and Zhou, Y. 2000. Water Saving Rice Culture in Northern China. Liaoning: Science Technology Publishing Company. (CE)

Wen, D., and Pimentel, D. 1992. Ecological resource management to achieve a productive, sustainable agricultural system in northeast China. Agriculture, Ecosystems and Environment (Amsterdam) 41: 215-230.

White, P. T. 1994. Rice-The essential harvest. $N a$ tional Geographic, 185 (5): 48-79.

Ying, L. 1999. China's changing regional disparities during the reform period. Economic Geography 75 (1): 59-70.

Zhang, L. 2000. Food distribution change in China and its reasons. Resources and Environment in the Yangze Basin 9(2): 221-228. (C)

Zhang, W., and Makeham J. 1992. Recent developments in the market for rural landuse in China. Land Economics 68(2): 139-162.

Zheng, X. 1999. Serious influence and its measure for population migration of China's Korean. Journal of Yanbian University (Social Science) 32(3): 66-73. (C)

$(\mathrm{J})$ : written in Japanese

(JE): written in Japanese with English abstract

(C): written in Chinese

(CE): written in Chinese with English abstract 